\title{
Purwarupa Alat Ukur Daya Listrik Berbasis Netduino Plus
}

\author{
Irma Nirmalasari ${ }^{* 1}$, Agfianto Eko Putra ${ }^{2}$, Bambang Nurcahyo Prastowo ${ }^{3}$ \\ ${ }^{1}$ Prodi Elektronika dan Instrumentasi Jurusan Ilmu Komputer dan Elektronika, FMIPA UGM \\ ${ }^{2,3}$ Jurusan Ilmu Komputer dan elektronika, FMIPA, UGM, Yogyakarta \\ e-mail: "11nirmalasari.irma@gmail.com, ${ }^{2}$ agfi@ugm.ac.id, ${ }^{3}$ prastowo@ugm.ac.id
}

\begin{abstract}
Abstrak
Seiring perkembangan teknologi banyak metode pengukuran arus, tegangan serta faktor daya yang dikembangkan. Pada penelitian ini dilakukan inovasi pengembangan sistem instrumentasi yaitu alat ukur daya listrik yang dapat diakses secara online sehingga informasi jumlah penggunaan daya listrik dan jumlah tagihan dapat diakses melalui website. Sistem ini dirancang menggunakan Netduino Plus berbasis ARM SAM7X, sensor ACS712 5A sebagai sensor arus dan juga menggunakan modul pengukur tegangan yang digunakan untuk mendeteksi tegangan dengan prinsip penyearah arus dan rangkaian pembagi tegangan. Mekanisme perhitungan penggunaan listriknya dilakukan dengan mengakumulasi daya yang dihitung setiap detik. Purwarupa alat ukur daya listrik ini berhasil dibuat dengan baik dan diketahui bahwa sensor arus pada sistem ini memiliki presentase keakuratan sebesar 98,4\%, pada modul pengukur tegangan memiliki presentase keakuratan sebesar 96,6\%.
\end{abstract}

Kata kunci-Alat Ukur Daya Listrik, Netduino Plus, ethernet, website

\begin{abstract}
Along with the development of technology a lot of methods of current, voltage and power factor measurement are developed. In this research is developing innovative instrumentation systems that use electrical power measuring devices that can be accessed online so that information on the number of power consumption and the amount of the bill can be accessed through the website. This system was designed using the Netduino Plus, ACS712 $5 A$ as sensor for detecting current and also use voltage gauges module that is used to detect the voltage with using the principle of current rectifier with a voltage divider circuit. The mechanism of usage electricity accumulation which is calculated for every second. Prototypes of electric power measuring instrument is successfully made and it is known that the current sensor system has the percentage accuracy of $98.4 \%$, the voltage measuring module has a percentage accuracy of $96.6 \%$.
\end{abstract}

Keywords-Power Measurement, Netduino Plus, ethernet, website

\section{PENDAHULUAN}

Seiring perkembangan teknologi banyak metode pengukuran arus, tegangan serta faktor daya Syang dikembangkan. Perusahaan Listrik Negara pun mulai mengganti penggunaan $\mathrm{kWh}$ meter konvensional dengan $\mathrm{kWh}$ meter digital untuk mengontrol pemakaian listrik agar sesuai dengan kebutuhan. Pemakaian listrik yang sesuai dengan kebutuhan menjadi hal yang sulit dicapai bagi sebagian besar pemilik usaha kos. Hal tersebut disebabkan banyaknya penghuni kos yang menggunakan listrik secara sembunyi-sembunyi, sehingga tagihan listrik menjadi tidak terkendali dan merugikan pemilik kos. Pemilik kos pada akhirnya membuat peraturan khusus untuk penghitungan pemakaian listrik. Biaya listrik dibebankan kepada penghuni kos berdasarkan jumlah alat elektronik yang dibawa, seperti televisi, komputer, laptop, dsb, 
sedangkan pada umumnya penghuni kos tersebut adalah mahasiswa yang memiliki beragam latar belakang kemampuan ekonomi, sehingga hal tersebut dirasakan kurang adil bagi penghuni yang jarang berada di kos namun dibebankan dengan biaya yang sama.

Pada beberapa penelitian yang telah dirancang sebelumnya yaitu Desain Alat Pengukur Energi Listrik Jarak Jauh Berbasis Mikrokontroler dengan Keakuratan yang Tinggi menggunakan mikrokontroler ATMega 16. Desain sistem alat ukur kWh-meter ini, terdiri dari beberapa alat ukur diantaranya alat pengukur beda fasa antara tegangan dan arus, pengukur tegangan dan pengukur arus. Alat ini juga dilengkapi dengan suatu pemancar yang digunakan untuk mengefektifkan sistem pencatatan dan pendataan yang nantinya akan dioperasikan oleh satu buah komputer yang telah diprogram secara langsung dapat menampilkan berapa besar biaya yang harus ditanggung oleh setiap pelanggan [1].

Di sisi lain perkembangan teknologi embedded ethernet yang sudah semakin pesat. Embedded ethernet juga merupakan suatu teknologi yang dapat diandalkan dalam membentuk suatu sistem jaringan jarak pendek-menengah [2]. Dengan tingkat kualitas jaringan yang sudah semakin baik yang dikolaborasikan dengan sistem pengukuran energi listrik ini dapat dijadikan penilitian tersendiri.

Pada penelitian sebelumnya juga telah dilakukan penelitian yang menggunakan sistem embedded ethernet yang memiliki TCP/IP stack didalam memorinya. Penggunaan embedded ethernet digunakan untuk pengendalian suhu ruangan menggunakan sensor LM 35DZ dan menggunakan mikrokontroller PIC 16F877 yang terkoneksi dengan jaringan ethernet. Modul yang digunakan yaitu Siteplayer produk embedded ethernet web server keluaran Netmedia. Untuk compiler program digunakan PIC Basic Pro sebagai compiler yang sesuai denga mikrokontroler PIC 16F877 [3].

Maka dari itu dibuat suatu sistem instrumentasi pengukuran energi listrik yang dapat melakukan akses total daya terpakai dan total tagihan yang dapat ditampilkan secara online.

\section{METODE PENELITIAN}

\section{1 Analisis Sistem}

Pada sistem ini menggunakan Netduino Plus, sensor arus, modul pengukur tegangan, MicroSD dan modul RTC Sistem ini diharapkan mampu melakukan akses energi listrik terpakai dan total tagihan yang dapat ditampilkan secara online.

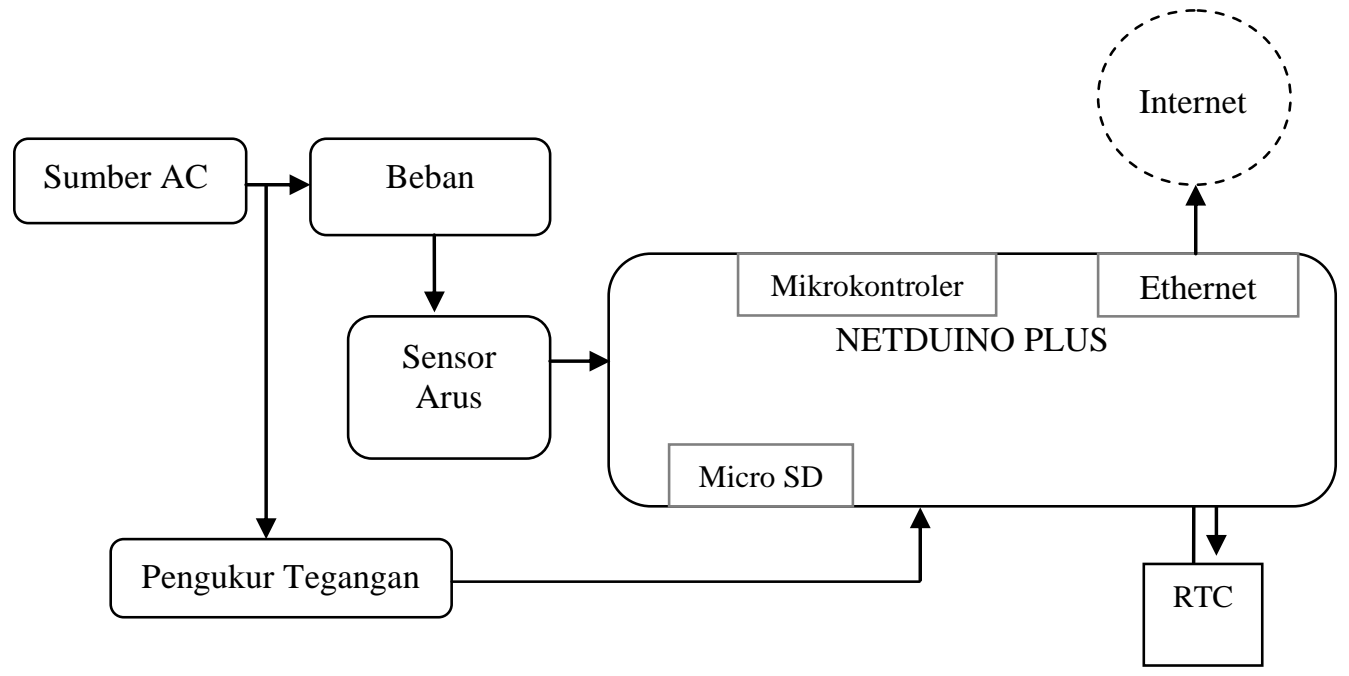

Gambar 1 Blok Diagram Sistem

Gambar 1 menunjukkan blok diagram sistem, beberapa komponen penting pada sistem ini seperti Netduino Plus, sensor arus yang digunakan adalah ACS712 5A, RTC yang digunakan

IJEIS Vol. 5, No. 1, April 2015: $21-30$ 
adalah DS 1307 dan microSD sebesar 2GB. Prinsip kerja sistem ini secara umum terdiri dari 5 langkah, yaitu :

1. Mengukur besar tegangan dan arus pada beban yang diukur.

2. Mengalikan kedua besaran tersebut (tegangan dan arus) untuk memperoleh daya sesaat.

3. Mengakumulasi hasil perkalian tegangan dan arus serta waktu penggunaan.

4. Dilakukan pengalian dengan tarif dasar listrik yang sesuai.

5. Menampilkan penggunaan daya listrik melalui website.

Fungsi rangkaian pengukur tegangan pada prinsipnya melakukan pencuplikan tegangan yang mengalir ke sistem pengukuran. Rangkaian ini terdiri dari travo step-down, penyearah arus, pembagi tegangan, dan buffer yang di lengkapi dengan kapasitor. Rangkaian dari pengukuran tegangan ditunjukan pada Gambar 2.

Pada sistem ini menggunakan modul IO yang terdiri dari rangkaian penstabil, pin Vcc serta pin ground. Rangkaian penstabil pada modul ini digunakan untuk luaran dari sensor arus agar stabil dan tidak lebih dari 3.3 Volt sehingga luaran dari penstabil ini dapat dimasukkan langsung pada port masukan analog Netduino. Pin Vcc dan ground pada modul ini dibutuhkan karena pin tersebut pada Netduino Plus berjumlah terbatas, sedangkan tak hanya sensor arus namun RTC juga membutuhkan pin tersebut, sehingga rangkaian modul sebagaimana ditunjukkan pada Gambar 3.

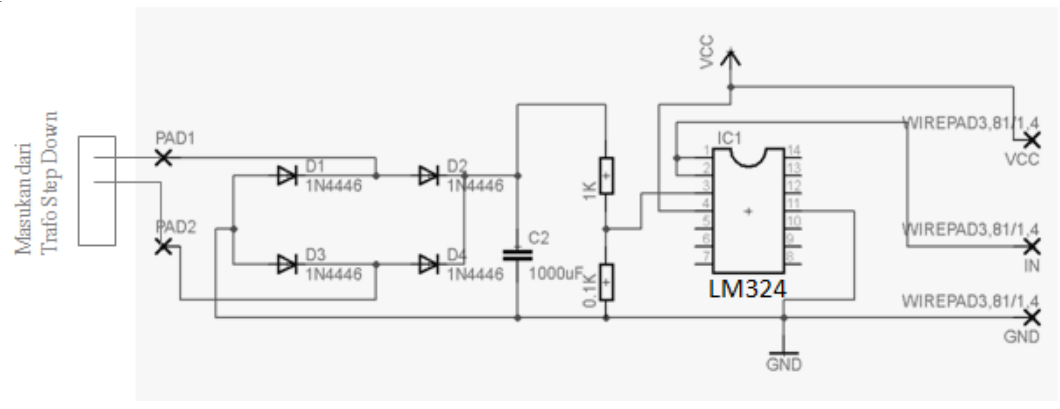

Gambar 2 Rangkaian skematik pengukuran tegangan

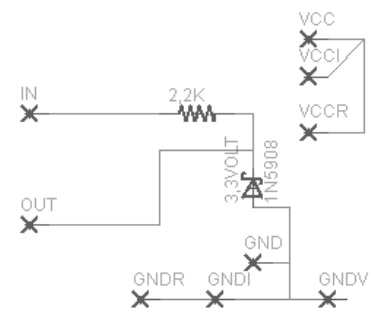

Gambar 3 Rangkaian Modul IO

Perancangan perangkat lunak pada sistem ini adalah perancangan program yang akan digunakan meliputi pemprograman sistem secara keseluruhan, algoritma perhitungan energi listrik, dan program antarmuka melalui Ethernet. Perancangan perangkat lunak sistem secara keseluruhan ditunjukan pada Gambar 4.

Pada Gambar 4, terdapat beberapa prosedur yang digunakan. Program diawali dengan inisialisasi awal sistem berupa variabel-variabel yang digunakan dan dilanjutkan dengan masukan nilai tegangan dan arus dari sensor arus dan pengukur tegangan yang digunakan sebagai perhitungan jumlah $\mathrm{kWh}$ dan disimpan dalam microSD.

Prosedur konversi data sensor arus dan pengukur tegangan seperti yang ditunjukkan pada Gambar 5. Pada prosedur tersebut dilakukan konversi dari tegangan masukan sensor arus dan pengukur tegangan menjadi nilai ADC dengan mengalikan tegangan masukan dengan tegangan 
refrensi dan dibagi dengan jumlah ADC. Untuk memperoleh nilai tegangan yang sesungguhnya dilakukan pengurangan nilai $\mathrm{ADC}$ dengan offset dan dibagi dengan gradien yang diperoleh dari kalibrasi sistem.

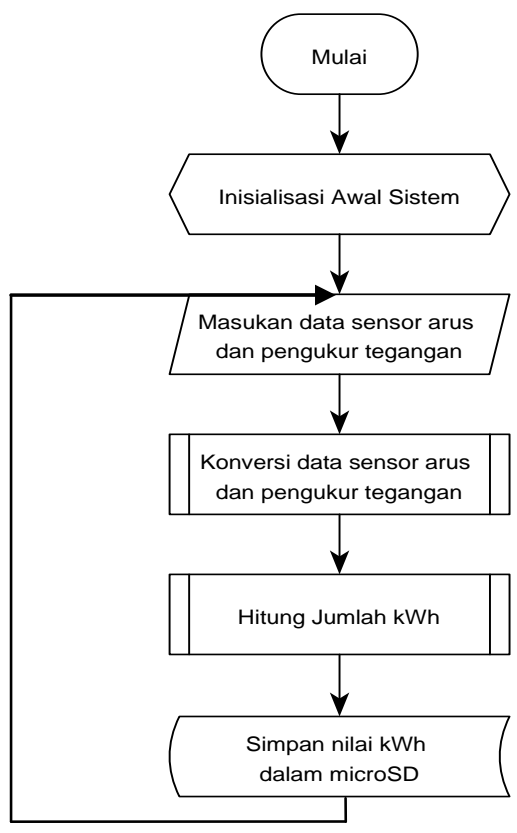

Gambar 4 Diagram Alir Sistem secara Keseluruhan

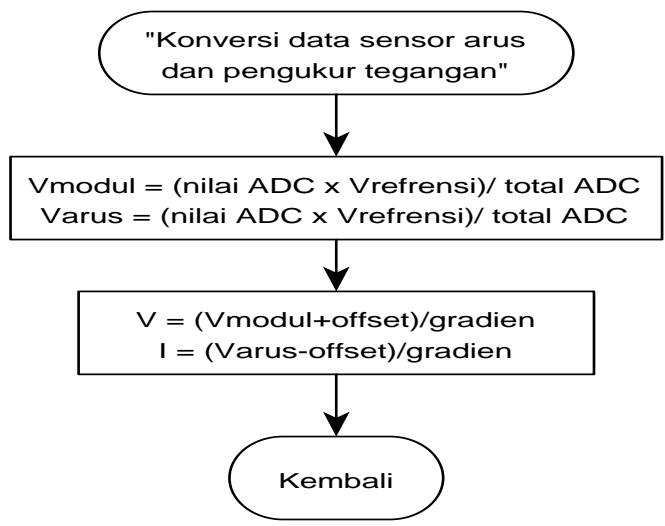

Gambar 5 Diagram Alir Prosedur Konversi Data Sensor Arus Dan Pengukur Tegangan

Pada Gambar 6 menunjukkan diagram alir prosedur Jumlah kWh. Pada prosedur perhitungan jumlah $\mathrm{kWh}$ dilakukan perhitungan nilai daya dengan rumus $\mathrm{P}=\mathrm{V}$.I. Untuk memperoleh energi total dilakukan pengambilan nilai energi sebelumnya yang tersimpan dalam microSD, kemudian dilakukan perhitungan nilai energi total dengan menjumlahkan nilai energi pada saat itu dengan nilai energi sebelumnya yang telah diambil.

Pada Gambar 7 merupakan diagram alir reply pada sistem ketika pengguna melakukan request pada browser. Ketika pengguna memasukkan alamat IP dari sistem ini, program menjawab dengan menampilkan data -data berupa jumlah daya yang telah digunakan, waktu akses serta jumlah tagihan yang sebelumnya dilakukan pengambilan nilai tersebut dari prosedur penghitungan energi.

Pada Gambar 8 merupakan prosedur respon pada sistem ketika pengguna melakukan request pada browser. Ketika pengguna memasukkan alamat IP dari sistem ini, program 
menjawab dengan menampilkan data - data berupa jumlah daya yang telah digunakan, waktu akses serta jumlah tagihan yang sebelumnya dilakukan pengambilan nilai tersebut dari prosedur penghitungan energi dan ditampilkan dalam format html.

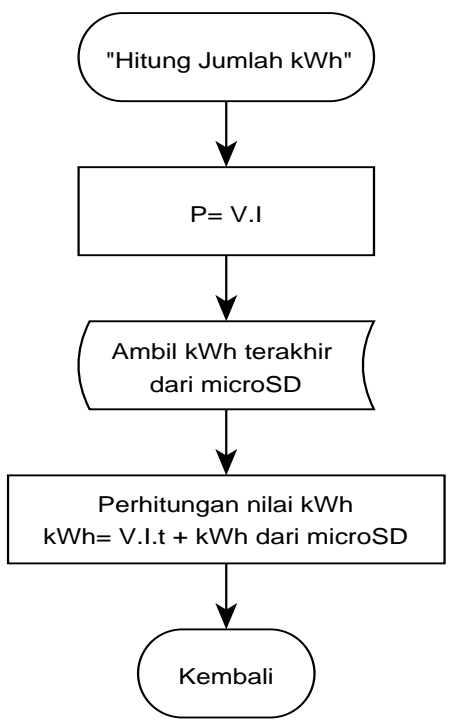

Gambar 6 Diagram Alir Prosedur Penghitungan kWh

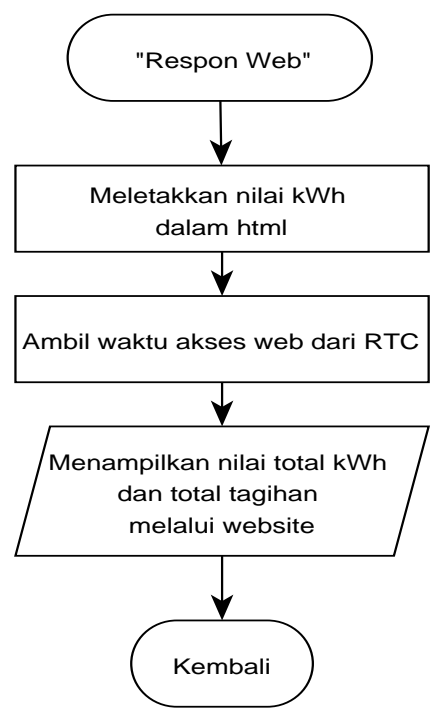

Gambar 7 Diagram Alir Interupsi Respon Web Browser

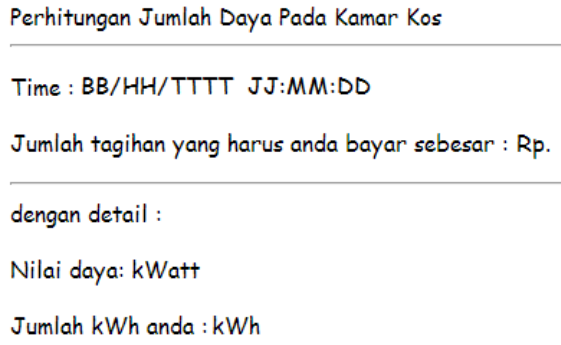

Gambar 8 Rancangan Tampilan Web 


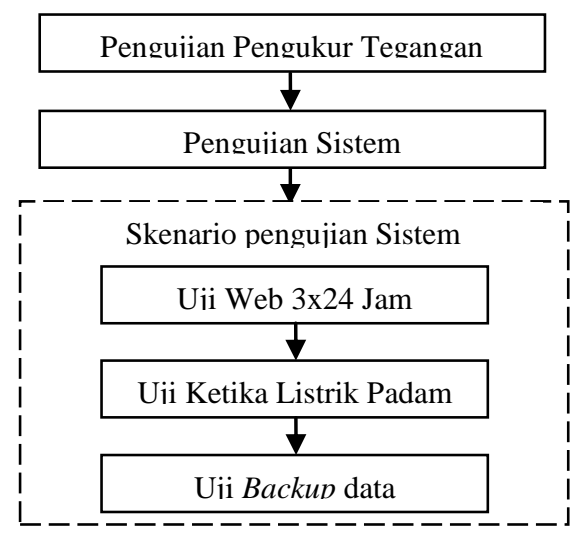

Gambar 9 Rancangan Pengujian Sistem

Gambar 9 menunjukkan rancangan pengujian sistem yang terdiri dari pengujian pengukur tegangan, pengujian sistem dan skenario pengujian sistem secara keseluruhan Skenario pengujian sistem terdiri dari pengujian web selama $3 \times 24$ jam untuk mengetahui ketahanan sistem agar sistem dapat bekerja sesuai dengan yang diharapan, pada pengujian ketika listrik mati tampilan pada website akan terlihat status yang menyatakan ketika listrik padam, dan pengujian backup data digunakan sebagai pengujian ketika catu netduino mati, sistem tetap memperoleh nilai $\mathrm{kWh}$ terakhir.

\section{2 Implementasi Sistem}

Pada Gambar 10 menunjukkan implementasi sistem secara keseluruhan, yang terdiri dari trafo stepdown, modul pengukur tegangan, sensor arus, modul IO, stop kontak, Netduino Plus dan RTC.

Gambar 11 menunjukkan implementasi rangkaian pengukur tegangan, rangkaian ini menggunakan prinsip penurunan tegangan masukan bolak balik (AC) menggunakan trafo stepdown dari 220 Volt menjadi 9 Volt. Kemudian dilakukan penyearah arus menggunakan dioda bridge agar menjadi tegangan searah (DC). Rangkaian buffer menggunakan IC LM324 N, yang berfungsi sebagai pengkondisian sinyal agar nilai keluaran pengukuran terbaca lebih stabil. Luaran dari LM324 ini akan digunakan sebagai masukan pada Netduino Plus yang memiliki tegangan batas sebesar 3,3 Volt DC.

Gambar 12 menunjukkan implementasi modul IO. Modul ini dibutuhkan karena keterbatasan pin VCC dan pin GND pada Netduino Plus. Modul ini terbagi menjadi dua, yaitu rangkaian penstabil untuk luaran sensor arus serta rangkaian pin VCC untuk sensor arus dan RTC. Rangkaian penstabil pada modul ini digunakan agar luaran dari sensor arus tidak lebih dari 3,3 Volt.

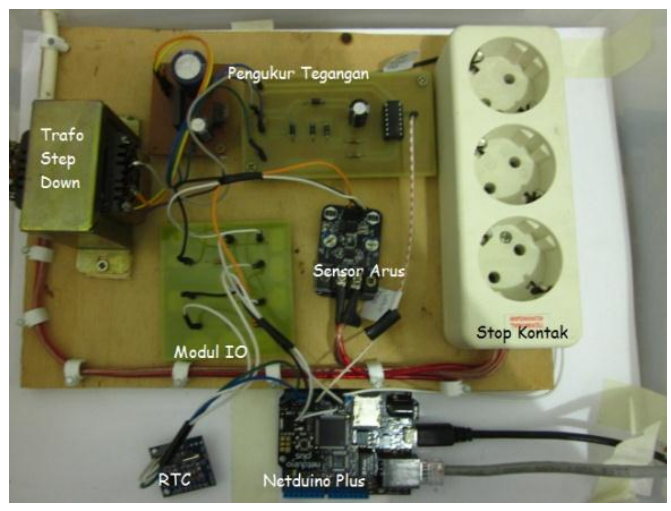

Gambar 10 Implementasi Perangkat Keras Secara Keseluruhan

IJEIS Vol. 5, No. 1, April 2015 : 21 - 30 


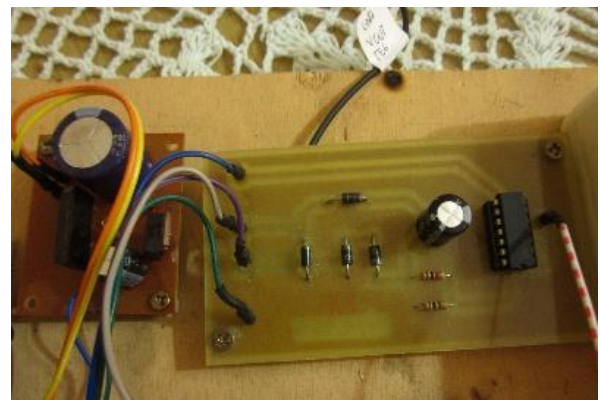

Gambar 11 Implementasi rangkaian pengukur tegangan

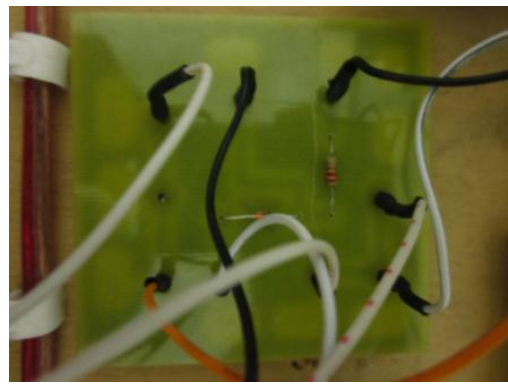

Gambar 12 Implementasi Modul IO

\section{HASIL DAN PEMBAHASAN}

Pada penelitian ini diperoleh hasil yang menjelaskan hasil pengujian pada penelitian dari purwarupa alat ukur daya listrik secara keseluruhan. Ada beberapa pengujian yang dilakukan pada sistem ini yaitu pengujian modul pengukur tegangan, pengujian sistem, sekenario pengujian ketika listrik padam, serta pengujian backup sistem.

Pada kalibrasi modul pengukur tegangan diperoleh diperoleh persamaan garis $\mathrm{Vo}=$ 0,005Vs-0,155 dengan koefisien penentu $\left(\mathrm{R}^{2}\right)$ sebesar 98,3\% sebagai persentase pengaruh variasi tegangan sumber dengan tegangan luaran trafo serta $\mathrm{Vo}=0,042 \mathrm{Vs}-0,782$ dengan koefisien penentu $\left(\mathrm{R}^{2}\right)$ sebesar 96,6\% untuk persentase pengaruh variasi tegangan sumber dengan tegangan luaran pada modul pengukur tegangan yang ditunjukkan pada Gambar 13.

Tegangan trafo Vs Tegangan modul

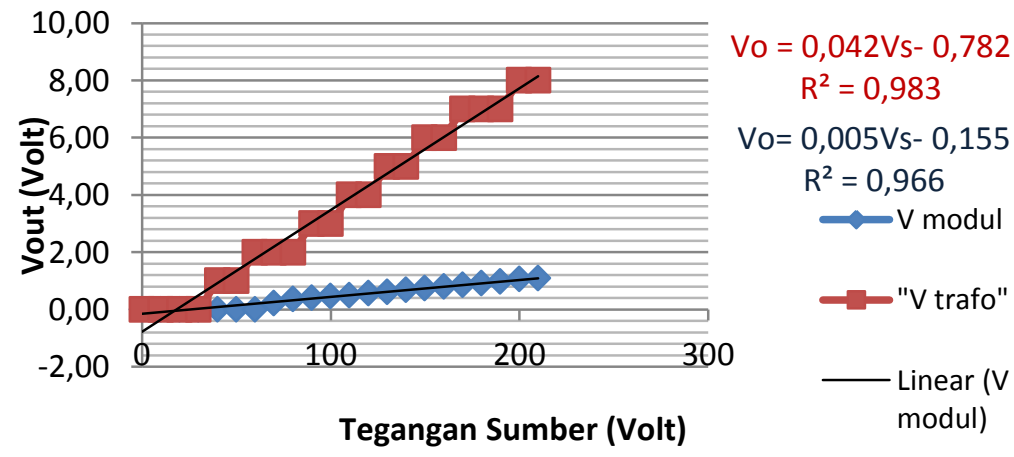

Gambar 13 Grafik Tegangan Luaran Trafo Vs Modul

Pada Gambar 14 merupakan pengujian pengukur tegangan, diperoleh fungsi linear VIo= 0,005 Vs-0,147 dengan nilai gradien sebesar 0,005 dan nilai intersep(offset) sebesar 0,147 yang digunakan sebagai nilai konversi menjadi nilai tegangan sumber kembali pada mikrokontroler 
dan memiliki nilai $\mathrm{R}^{2}$ sebesar 0,999 dengan presentase pengaruh antara tegangan sumber dengan egangan luaran modul sebesar $99,9 \%$.

\section{Grafik VIOUT Modul dengan Tegangan Sumber}

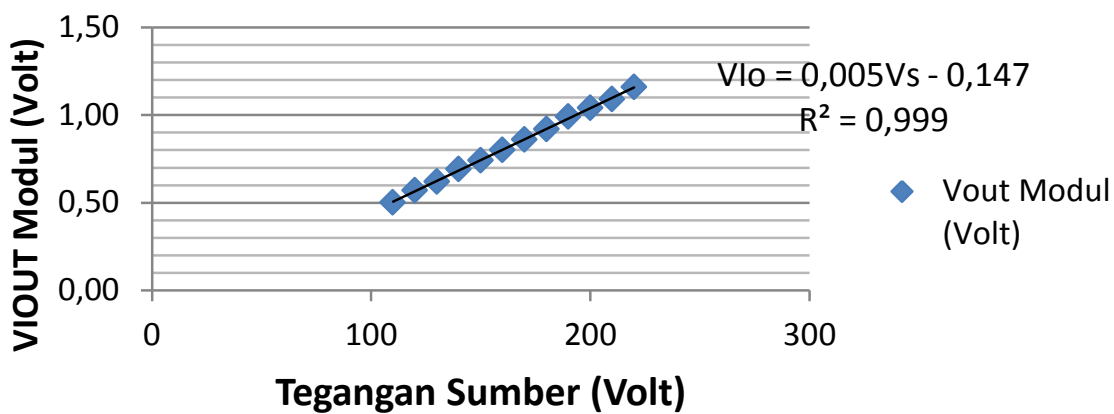

Gambar 14 Grafik Vout Modul dengan Tegangan Sumber

Kalibrasi sensor arus diperoleh persamaan garis $\mathrm{VI}_{\mathrm{A}}=0,089 \mathrm{I}_{\mathrm{w}}+2,34$ dengan gradien sebesar 0,089 dan nilai offset sebesar 2,34 yang digunakan pada proses perhitungan mikrokontroler untuk mengkonversi nilai keluaran sensor arus dari VIOUT menjadi nilai arus dalam Ampere dengan nilai $R^{2}=0,984$ yang menunjukkan sebagai presentase pengaruh grafik dengan kesesuaian pola simpangan sebesar 98,4\% seperti yang ditunjukkan pada Gambar 15.

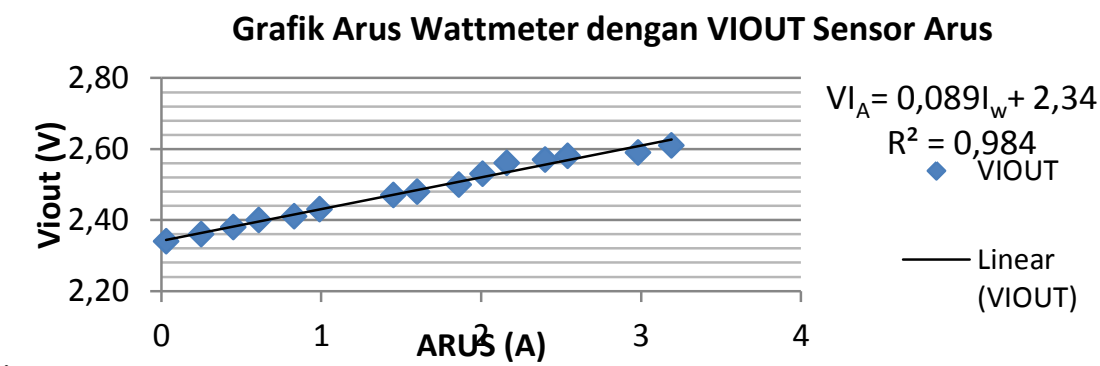

Gambar 15 Grafik Arus Wattmeter dengan VIOUT Sensor Arus

Pengujian sistem dilakukan dengan memberikan variasi beban dari 100 hingga 810 Watt untuk memperoleh nilai pembacaan ADC pada mikrokontroler. Sebagai pembanding pada pengujian ini digunakan pengukuran menggunakan wattmeter yang telah terkalibrasi dengan baik dan tegangan sumber sebesar 200 Volt. Kemudian dilakukan analisa regresi linear sehingga pada pengujian sistem diperoleh fungsi linear $I_{A}=0,996 I_{w}-0,003$ dengan 0,996 sebagai gradien garis dan 0,003 sebagai nilai offset. Pada grafik tersebut memiliki nilai $\mathrm{R}^{2}$ sebesar 0,982 sehingga memiliki presentase pengaruh grafik dengan kesesuaian pola simpangan sebesar 98,4\% seperti yang ditunjukkan pada Gambar 16.

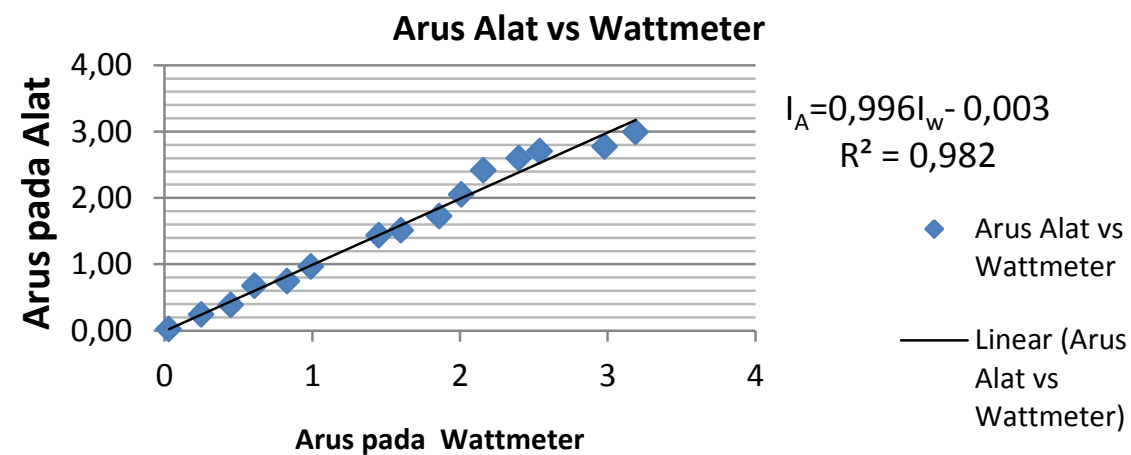

Gambar 16 Grafik Antara Arus Alat dengan Arus Wattmeter

IJEIS Vol. 5, No. 1, April 2015: $21-30$ 
Pada pengujian tampilan web menggunakan browser, dengan melakukan request pada sistem. Apabila ada request dari client maka sistem akan mengirimkan respon berupa informasi mengenai sistem, baik dari nilai daya yang tedeteksi pada saat itu, jumlah energi dan jumlah tagihan yang harus dibayarkan. Seperti ditunjukkan pada Gambar 17(a) hingga 17(d). Pengujian web server ini dilakukan selama $72 \mathrm{jam}$.

Gambar 18 menunjukkan skenario pengujian ketika listrik padam dilakukan dengan mencabut kabel yang menghubungkan alat dengan sumber listrik. Ketika pengujian alat dari sistem ini tidak mengalami pemadaman, karena Netduino Plus memiliki sumber catu daya sendiri. Netduino Plus akan padam ketika sumber dari catu daya tersebut mati.

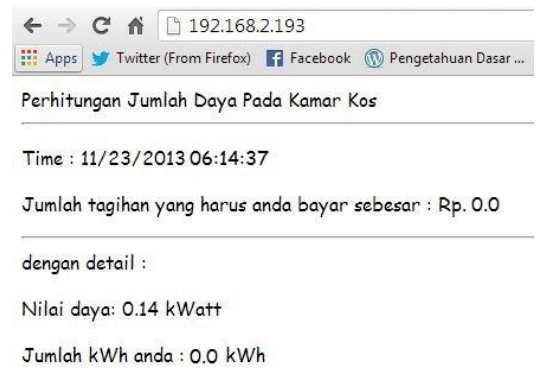

(a)

\begin{tabular}{|c|}
\hline :i: Apps Twitter (From Firefox) If Facebook (1) Pengetahuan Dasar ... E N N \\
\hline Perhitungan Jumlah Daya Pada Kamar Kos \\
\hline Time : 11/25/2013 06:32:19 \\
\hline Jumlah tagihan yang harus anda bayar sebesar : Rp. 8842.7 \\
\hline dengan detail : \\
\hline Nilai daya: $0.24 \mathrm{kWatt}$ \\
\hline Jumlah kWh anda : $9.825 \mathrm{kWh}$ \\
\hline
\end{tabular}

(c)

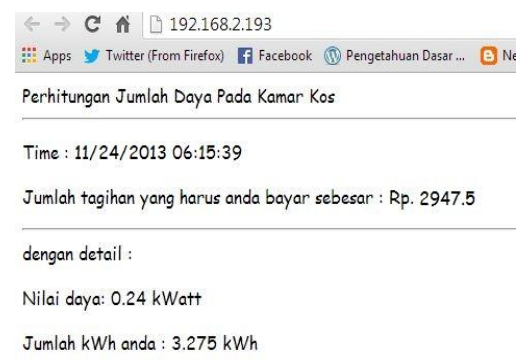

(b)

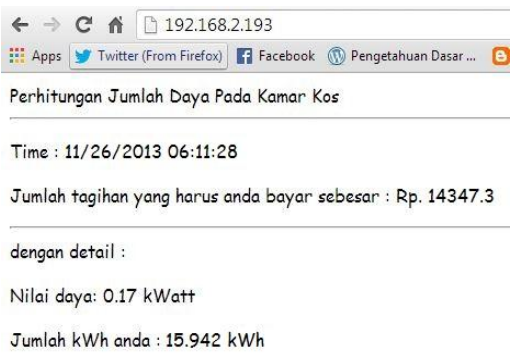

(d)

Gambar 17 (a) Uji tampilan Pukul 6:14 (b) Uji tampilan 24 jam (c )Uji tampilan 48 jam (d) Uji tampilan 72 jam

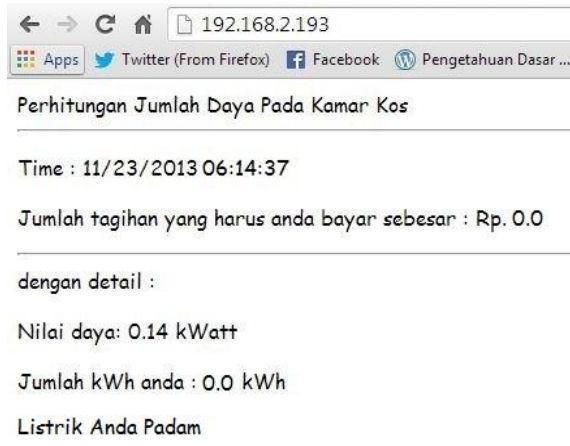

Gambar 18 Pengujian Listrik Padam

Pengujian backup data seperti yang ditunjukkan pada Gambar 19, Pada pengujian terakhir dilakukan penyimpanan pada tanggal 26 November 2013 pada pukul 6:11:28 dengan nilai energi akumulasi sebesar $15.941762 \mathrm{kWh}$. Ketika alat padam, back up data dapat dilakukan secara seketika saat sistem menyala dan mulai berjalan kembali. 


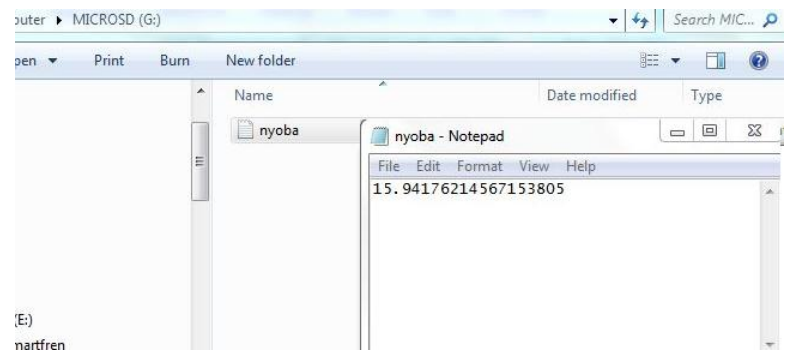

Gambar 19 Hasil uji backup data

\section{KESIMPULAN}

Dari penelitian yang telah dilakukan dan dapat diambil kesimpulan bahwa telah berhasil dibuat sebuah analisis penghitung penggunaan daya kamar dengan webserver berbasis Netduino Plus dengan fitur:

1. Secara keseluruhan sistem ini dapat melakukan akumulasi jumlah penggunaan listrik dengan baik dan besar tagihan dapat diakses secara online.

2. Modul pengukur tegangan memiliki presentase keakuratan sebesar $96,6 \%$ dengan keakuratan trafo stepdown sebesar 98,3\%.

3. Sensor arus memiliki presentase keakuratan sebesar $98,4 \%$.

\section{SARAN}

Pada penelitian ini masih terdapat beberapa hal yang perlu disempurnakan. Berikut saransaran yang disampaikan untuk penelitian selanjutnya yang sejenis.

1. Hendaknya sistem dapat ditingkatkan keakurasian pada sensor arus dan pengukur tegangan, sehingga dapat meningkatkan tingkat akurasi pada perhitungan dayanya.

2. Hendaknya sistem dapat ditingkatkan pada pengaturan nilai Tarif Dasar Listrik melalui website.

\section{DAFTAR PUSTAKA}

[1] Pratomo, L.H., 2005, Desain Alat Pengukur Energi Listrik Jarak Jauh Berbasis Mikrokontroller dengan Keakuratan yang Tinggi, Skripsi, Laboratorium Konversi Energi Listrik, Fakultas Teknologi Industri Jurusan Teknik Elektro, Universitas Katolik Soegijapranata, Semarang.

[2] Octavino, N., 2007, Sistem Embedded Ethernet untuk mengendalikan suhu ruangan melalui protocol TCP/IP, Skripsi, Fakultas Matematika dan Ilmu Pengetahuan Alam. Universitas Gadjah Mada, Yogyakarta.

[3] Alfian, R.M dan Subali, 2010, Web Server Berbasis Embadded Ehernet untuk Sistem Kendali dan Monitoring Jarak Jauh pada Ruang Penyimpanan Barang Berharga, Laporan Tugas Akhir, Fakultas Teknik, Universitas Diponegoro, Semarang. 